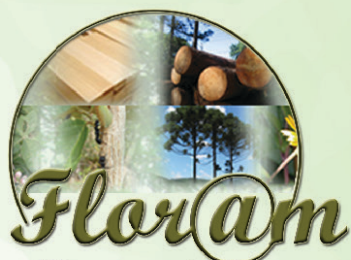

Floresta e Ambiente

\title{
Production of Structural Particleboard of Mimosa Scabrella Benth With Lignin Phenol-formaldehyde Resin
}

\author{
Viviane Teixeira Iwakiri ${ }^{1}$ (D), Rosilani Trianoski ${ }^{1}$ (D), Dalton Luiz Razera ${ }^{1}$ (D), \\ Setsuo Iwakiri ${ }^{1}$ (D), Thiago Souza da Rosa ${ }^{1}$
}

${ }^{1}$ Universidade Federal do Paraná - UFPR, Curitiba/PR, Brasil

\begin{abstract}
The objective of this work was to evaluate the feasibility of using lignin-phenol-formaldehyde resin in the production of Mimosa scabrella Benth (bracatinga) structural particleboard. The boards were produced with nominal specific mass of 0.75 and $0.95 \mathrm{~g} / \mathrm{cm}^{3}, 10 \%$ and $12 \%$ of phenol-formaldehyde and lignin-phenol-formaldehyde resins, with 10 and 12 min of pressing time. The boards quality was evaluated by means of the following physical-mechanical tests: specific mass, compression ratio, water absorption and thickness swelling after 2 and 24 hours soaking, perpendicular traction, static bending and screw pulling. Positive interactions of specific mass, resin content and pressing time were observed in the properties of the boards produced. The evaluation of the properties results based on the requirements of EN 312 (type P5) standard indicated the feasibility of using lignin-phenol-formaldehyde resin in the production of particleboard of Mimosa scabrellla for structural applications.
\end{abstract}

Keywords: phenolic resin, bracatinga, structural boards.

\section{Produção de painel aglomerado estrutural de Mimosa scabrella Benth com resina lignina-fenol-formaldeído}

\begin{abstract}
RESUMO
O objetivo do trabalho foi avaliar a viabilidade de uso da resina lignina-fenol-formaldeído na produção de painel aglomerado estrutural de Mimosa scabrella Benth (bracatinga). Os painéis foram produzidos com massa específica nominal de $750 \mathrm{~kg} \cdot \mathrm{m}^{-3} \mathrm{e} 950 \mathrm{~kg} \cdot \mathrm{m}^{-3}, 10$ e $12 \%$ de resina fenol-formaldeído e lignina-fenol-formaldeído, e 10 e 12 minutos de prensagem. A qualidade dos painéis experimentais foi avaliada por meio de seguintes ensaios físico-mecânicos: massa específica, razão de compactação, absorção de água e inchamento em espessura 2 e 24 horas, tração perpendicular, flexão estática e arrancamento de parafuso. Foram constatadas interações positivas da massa específica, teor de resina e tempo de prensagem nas propriedades dos painéis produzidos. A avaliação dos resultados das propriedades com base nos requisitos da norma EN 312:2003 (tipo P5), indicaram a viabilidade de uso da resina lignina-fenol-formaldeído na produção de painel aglomerado de Mimosa scabrellla para aplicações estruturais.
\end{abstract}

Palavras-chave: resina fenólica, bracatinga, painéis estruturais. 


\section{INTRODUCTION}

The urea-formaldehyde and phenol-formaldehyde resins are the main types of thermoset synthetic adhesives used by industries of wood boards. The phenol-formaldehyde is the most used in the production of boards for structural purposes intended for external environment, with or without protection, such as plywood and OSB.

The synthetic adhesives are composed of organic origin which derive mostly from petroleum. Its formulation contains toxic components harmful to the environment when disposed improperly. Due to the pressures for materials and processes that mitigate the environmental impacts, interest grows in natural adhesives such as the soy-based, castor polyurethane resin, and those consisting of lignocellulosic residues, such as the lignin and tannins.

The lignin-based adhesives from the wood pulping process surplus to obtain cellulose are aligned with the interest described above for two main reasons: they 1) employ raw materials from renewable sources and from scrap of industrial production, and 2) promote a reduction in the use of synthesized components with phenol and urea, when mixed with conventional adhesives.

The residual lignin from black liquor, a by-product of the process of obtaining cellulose pulp for paper manufacture, is considered a surplus, since the industry is unable to deal with all the black liquor generated, given the high cost of the recovery boiler. A negligible percentage of lignin is precipitated and marketed (from 1 to $2 \%$ ) and the remainder is used in the industry itself for energy generation by means of burning. However, there is a strong global trend of exploiting this lignin surplus for more noble purposes, such as adhesives for wood. Several studies have been carried out from various sources and forms of extraction of lignin with the goal of adding it to the phenolic adhesives for wood bonding.

For Alonso et al. (2004) and Çetin \& Özmen (2002), the lignin shows great potential for various industrial purposes, among which stands out its use as a substitute of phenol. Gothwal et al. (2010) found that the replacement of phenol by lignin in phenol-formaldehyde adhesive in up to $15 \%$ did not alter the particleboard physical properties. Thus, the formulation not only met the specifications of the standard regarding resistance to shearing, but also revealed good reactivity, enabling a pressing time comparable to conventional phenolic adhesive. Kouisni et al. (2011) attested, in turn, the possibility of substitution of up to $30 \%$ of phenol by lignin in phenol-formaldehyde adhesive without significantly affecting the particleboard mechanical properties. Akhtar et al. (2011) evaluated specimen made with lignin-based resin in dry conditions and after immersion in water. The authors found no significant difference in the values of shear strength, which indicates that the lignin-based adhesives are water resistant. This characteristic is important under the viability standpoint regarding the use of the lignin-phenol-formaldehyde resin for the structural particleboard production for use in external environments.

In relation to the wood, in Brazil the species of the genus Pinus and Eucalyptus from forest plantations are the most used for the particleboard production. Studies have been carried out to evaluate the potential use of various species of fast-growing alternative to wood supply for the particleboard industries, which require large volume of timber. However, Mimosa scabrella (bracatinga), native species in the southern region of Brazil, can also be an important source to aggregate volume in the raw material matrix for the particleboard production.

Bracatinga has natural occurrence from the south of the state of Minas Gerais to the north of Rio Grande do Sul, with predominance in the states of Paraná and Santa Catarina. It is a deciduous and leafy species, may reach adulthood until $29 \mathrm{~m}$ in height and $50 \mathrm{~cm}$ or more in diameter (Carvalho, 2003). In relation to wood, bracatinga has moderate density, with values ranging from 0.65 to $0.81 \mathrm{~g} / \mathrm{cm}^{3}$ (Carvalho, 2003), which makes it a good option for use in the furniture production and constructive components. Its wood is obtained from natural forest regeneration and commercial plantations. It has been used as firewood, charcoal and props in civil construction.

In the choice of species for the particleboard production the wood density is an important requirement, with a view to its influence on the panel compaction ratio. According to Moslemi (1974), the compression ratio is the ratio between the panel specific mass and the wood and must be at least 1.3 to ensure an adequate contact area among the particles and the enough densification 
of the panel. Maloney (1993) states that, for boards of same density, those that are produced with low-density wood will have superior mechanical properties, however, its dimensional stability will be impaired due to the higher compaction ratio. Moslemi (1974) states that the species with density of up to $0.55 \mathrm{~g} / \mathrm{cm}^{3}$ are the most suitable for the wood particleboards due to achieving compaction ratio between 1.3 and 1.6.

In view of the above, the objective of this work was to evaluate the potential use of the resin lignin-phenol-formaldehyde in replacing the conventional phenol-formaldehyde resin in the particleboard for structural purposes using the wood of Mimosa scabrella Benth.

\section{MATERIAL AND METHODS}

In this research, wood of Mimosa scabrella Benth (bracatinga) purchased in local commerce was used in the form of props in civil construction, with diameter between 10 and $15 \mathrm{~cm}$ and a length of $3.0 \mathrm{~m}$ from the base of the trees. The resins used in the particleboards production were the experimental lignin-phenol-formaldehyde, in development phase by Suzano Celulose e Papel, and commercial phenol-formaldehyde, used as a control, with solids content of $49.4 \%$ and $54.6 \%$, respectively. The paraphinic emulsion was used with the purpose of reducing the water absorption and improving the particleboards dimensional stability.

Before being processed in the form of particles, the props of bracatinga were sectioned in parts of $10 \mathrm{~cm}$, of which 14 were selected to determine the basic density of the wood.

The particles were generated in disc chipper with the nominal thickness of $0.7 \mathrm{~mm}$ and air-dried. They were subsequently reprocessed in hammer mill for conversion into smaller particles, using sieves with mesh of $12 \mathrm{~mm}$ and $6 \mathrm{~mm}$. Once chewed, the particles were sieved in automatic sampler with 30-mesh sieve to remove thin particles. Then the particles were dried in an oven at $103{ }^{\circ} \mathrm{C}$ until $3 \%$ moisture and stored in plastic packaging.

The homogeneous type boards were produced with the dimensions of $50.0 \times 38.0 \times 1.3 \mathrm{~cm}$ and density rating of 0.75 and $0.95 \mathrm{~g} / \mathrm{cm}^{3}$, using commercial phenol-formaldehyde resin and experimental lignin-phenol-formaldehyde with solids content of $10 \%$ and $12 \%$. The boards were pressed at the temperature of $160{ }^{\circ} \mathrm{C}$, specific pressure of $40 \mathrm{kgf} / \mathrm{cm}^{2}$ and pressing time of 10 and $15 \mathrm{~min}$. The study variables are presented in Table 1 experimental plan.

After pressing, the boards were trimmed and packaged in climatic chamber at a temperature of $20 \pm 3{ }^{\circ} \mathrm{C}$ and relative humidity of $65 \pm 5 \%$. The physical and mechanical testing were performed in accordance with the procedures described in the ABNT NBR 14810-2:2013 for the following properties: density, water absorption and thickness swelling, modulus of elasticity and rupture in static bending, perpendicular traction and screw pulling resistance (ABNT, 2013).

The testing results were confronted with the requirements of European standards EN 312:2003 and Brazilian Standard NBR 14810-2:2013 for structural particleboard for use in wet conditions - type P5 (EN, 2003).

The experimental design was a factorial $2 \times 2 \times 2 \times 2$ for the purposes of the types of resin, board density, resin content and pressing time. It was applied to the analysis of variance (ANOVA) for verification of significant effects of the treatments at $5 \%$ probability

Table 1. Experimental plan.

\begin{tabular}{|c|c|c|c|c|}
\hline Treatment & Type of resin & $\begin{array}{l}\text { Panel density } \\
\left(\mathrm{g} / \mathrm{cm}^{3}\right)\end{array}$ & $\begin{array}{c}\text { Resin Content } \\
(\%)\end{array}$ & $\begin{array}{l}\text { Pressing time } \\
\text { (min) }\end{array}$ \\
\hline $\mathrm{T} 1$ & \multirow{4}{*}{$\mathrm{FF}$} & \multirow{2}{*}{0.75} & 10 & 10 \\
\hline $\mathrm{T} 2$ & & & 12 & 15 \\
\hline T3 & & \multirow{2}{*}{0.95} & 10 & 10 \\
\hline $\mathrm{T} 4$ & & & 12 & 15 \\
\hline T5 & \multirow{4}{*}{ LFF } & \multirow{2}{*}{0.75} & 10 & 10 \\
\hline T6 & & & 12 & 15 \\
\hline $\mathrm{T} 7$ & & \multirow{2}{*}{0.95} & 10 & 10 \\
\hline T8 & & & 12 & 15 \\
\hline
\end{tabular}

$\mathrm{FF}=$ phenol-formaldehyde resin; $\mathrm{LFF}=$ lignin phenol formaldehyde resin. 
of error, and the Tukey test for comparison of means at the level of probability of $95 \%$. The statistical program Statgraphics Centurion XVI was used.

\section{RESULTS AND DISCUSSIONS}

\subsection{Physical properties of particleboard}

In Table 2 are presented the mean values of density and compaction ratio of the boards.

The average values of the board densities range from $730 \mathrm{~kg} \cdot \mathrm{m}^{-3}$ (T1) to $740 \mathrm{~kg} \cdot \mathrm{m}^{-3}$ (T6) for the boards produced with nominal density of $750 \mathrm{~kg} \cdot \mathrm{m}^{-3}$; and $910 \mathrm{~kg} \cdot \mathrm{m}^{-3}$ for all boards produced with nominal density of $950 \mathrm{~kg} \cdot \mathrm{m}^{-3}$. No significant differences were observed between the boards with the same density. The average values obtained were somewhat inferior

Table 2. Mean values of boards density and compaction ratio.

\begin{tabular}{|c|c|c|}
\hline Treatment & $\begin{array}{c}\mathrm{ME} \\
\left(\mathrm{kg} \cdot \mathrm{m}^{-3}\right)\end{array}$ & $\mathbf{R C}$ \\
\hline T1 - FF/dp750/tr10/tp10 & $730 \mathrm{~b}(4.42)$ & $1.40 \mathrm{~b}(4.42)$ \\
\hline $\mathrm{T} 2-\mathrm{FF} / \mathrm{dp} 750 / \operatorname{tr} 12 / \mathrm{tp} 15$ & $740 \mathrm{~b}(4.70)$ & $1.42 \mathrm{~b}(4.70)$ \\
\hline T3 - FF/dp950/tr10/tp10m & 910 a (3.95) & $1.75 \mathrm{a}(3.95)$ \\
\hline T4 - FF/dp950/tr12/tp15 & 910 a (5.36) & $1.75 \mathrm{a}(5.36)$ \\
\hline T5 - LFF/dp750/tr10/tp10 & $730 \mathrm{~b}(4.47)$ & $1.41 \mathrm{~b}(4.47)$ \\
\hline T6 - LFF/dp750/tr12/tp15 & $740 \mathrm{~b}(5.44)$ & $1.44 \mathrm{~b}(5.44)$ \\
\hline T7 - LFF/dp950/tr10/tp10m & 910 a (5.55) & $1.76 \mathrm{a}(5.55)$ \\
\hline T8 - LFF/dp950/tr12/tp15 & 910 a (5.46) & $1.75 \mathrm{a}(5.46)$ \\
\hline
\end{tabular}

$\mathrm{ME}=$ specific mass; $\mathrm{RC}=$ compaction ratio; $\mathrm{FF}=$ phenolformaldehyde resin; $\mathrm{LFF}=$ lignin phenol formaldehyde resin; dp750 = panel density of $750 \mathrm{~kg} \cdot \mathrm{m}^{-3} ; \mathrm{dp} 950=$ panel density of $950 \mathrm{~kg} \cdot \mathrm{m}^{-3} ; \mathrm{tr}=$ volatile resin; $\mathrm{tp}=$ pressing time. Averages followed by the same letter at the column are statistically equal by the Tukey test at $95 \%$ of probability. Values between brackets refer to the coefficient of variation. to the density calculated of 750 and $950 \mathrm{~kg} \cdot \mathrm{m}^{-3}$ due to the effects like loss of materials during the mattress formation and return in board thickness after pressing and conditioning.

The average values of the boards compaction ratio calculated for wood density of Bracatinga of $520 \mathrm{~kg} \cdot \mathrm{m}^{-3}$ ranged from 1.40 to 1.44 for the boards produced with nominal density of $750 \mathrm{~kg} \cdot \mathrm{m}^{-3}$; and from 1.75 to 1.76 for the boards with nominal density of $950 \mathrm{~kg} \cdot \mathrm{m}^{-3}$. The results are in accordance with the minimum value of 1.30 recommended by Moslemi (1974) for particleboards.

In Table 3 are presented the mean values of water absorption and thickness swelling after 2 and 24 hours of immersion in water.

The average values of water absorption after 2 hours of immersion ranged from $6.71 \%$ (T8) for the boards produced with $12 \%$ LFF resin, density of $950 \mathrm{~kg} \cdot \mathrm{m}^{-3}$ and $15 \mathrm{~min}$ of pressing to $18.70 \%$ (T1) for the boards produced with $10 \%$ FF resin, density of $750 \mathrm{~kg} \cdot \mathrm{m}^{-3}$ and $10 \mathrm{~min}$ of pressing. Statistically significant differences were observed between the tested treatments.

For the water absorption after 24 hours of immersion, the average values ranged from $23.24 \%$ (T8) for the boards produced with $12 \%$ LFF resin, density of $950 \mathrm{~kg} \cdot \mathrm{m}^{-3}$ and $15 \mathrm{~min}$ of pressing to $44.49 \%$ (T1) for the boards produced with $10 \%$ FF resin, density of $750 \mathrm{~kg} \cdot \mathrm{m}^{-3}$ and 10 min of pressing. Statistically significant differences were observed between the tested treatments.

The average values of thickness swelling after 2 hours of immersion ranged from $4.23 \%$ (T6) for the boards produced with $12 \%$ LFF resin, density of $750 \mathrm{~kg} \cdot \mathrm{m}^{-3}$ and $15 \mathrm{~min}$ of pressing to $8.22 \%$ (T7) for the boards

Table 3. Mean values of the physical properties of particleboard.

\begin{tabular}{|c|c|c|c|c|}
\hline Treatment & WA 2 h (\%) & WA 24 h (\%) & TS 2 h (\%) & TS $24 \mathrm{~h}(\%)$ \\
\hline $\mathrm{T} 1$ - FF/dp750/tr10/tp10 & $18.70 \mathrm{a}(20.65)$ & 44.49 a (10.87) & $4.93 \mathrm{~cd}(22.52)$ & $12.55 \mathrm{bc}(13.50)$ \\
\hline $\mathrm{T} 2$ - FF/dp750/tr12/tp15 & $13.06 \mathrm{c}(14.53)$ & $36.18 \mathrm{~b}(8.33)$ & $4.55 \mathrm{~d}(19.58)$ & $10.82 \mathrm{~d}(9.80)$ \\
\hline T3 - FF/dp950/tr10/tp10m & $8.00 \mathrm{~d}(15,82)$ & $25.00 \mathrm{~cd}(13.38)$ & $4.51 \mathrm{~d}(24.65)$ & $10.89 \mathrm{~d}(17.31)$ \\
\hline T4 - FF/dp950/tr12/tp15 & $8.03 \mathrm{~d}(16,92)$ & $24.90 \mathrm{~cd}(15.24)$ & $7.18 \mathrm{ab}(19.11)$ & $11.49 \mathrm{~cd}(10.07)$ \\
\hline T5 - LFF/dp750/tr10/tp10 & $15.86 \mathrm{ab}(18.38)$ & $42.90 \mathrm{a}(5.92)$ & 5.95 c (13.63) & $13.3 \mathrm{~b}(14.06)$ \\
\hline T6 - LFF/dp750/tr12/tp15 & $13.86 \mathrm{bc}(21,62)$ & $34.69 \mathrm{~b}(9.65)$ & $4.23 \mathrm{~d}(12.38)$ & $10.14 \mathrm{~d}(5.33)$ \\
\hline T7 - LFF/dp950/tr10/tp10m & $8.83 \mathrm{~d}(16,60)$ & 28.79 c (14.25) & $8.22 \mathrm{a}(18.44)$ & 15.59 a $(9.80)$ \\
\hline T8 - LFF/dp950/tr12/tp15 & $6.71 \mathrm{~d}(14,69)$ & $23.24 \mathrm{~d}(13.75)$ & $6.25 \mathrm{bc}(15,18)$ & $10.57 \mathrm{~d}(13.90)$ \\
\hline
\end{tabular}

$\mathrm{FF}=$ phenol-formaldehyde resin; $\mathrm{LFF}=$ lignin phenol formaldehyde resin; dp750 = board density of $750 \mathrm{~kg} \cdot \mathrm{m}^{-3}$; dp950 = board density of $950 \mathrm{~kg} \cdot \mathrm{m}^{-3} ; \mathrm{tr}=$ resin content; $\mathrm{tp}=$ pressing time; $\mathrm{WA}=$ water absorption; TS = thickness swelling. Averages followed by the same letter at the column are statistically equal by the Tukey test at $95 \%$ of probability. Values between brackets refer to the coefficient of variation. 
produced with $10 \% \mathrm{FF}$ resin, density of $950 \mathrm{~kg} \cdot \mathrm{m}^{-3}$ and $10 \mathrm{~min}$ of pressing. Statistically significant differences were observed between the tested treatments.

For the thickness swelling after 24 hours of immersion, the average values ranged from $10.14 \%$ (T6) for the boards produced with $12 \%$ LFF resin, density of $750 \mathrm{~kg} \cdot \mathrm{m}^{-3}$ and $15 \mathrm{~min}$ of pressing to $15.59 \%$ (T7) for the boards produced with $10 \%$ FF resin, density of $950 \mathrm{~kg} \cdot \mathrm{m}^{-3}$ and $10 \mathrm{~min}$ of pressing. Statistically significant differences were observed between the tested treatments.

For evaluation of the board quality the requirements of European and Brazilian standards (EN and NBR) are taken as reference. However, none of the standards specify requirements for the water absorption testing.

For the thickness swelling, those standards specify that structural particleboards for use in wet conditions (P5), with a nominal thickness between 13 and $20 \mathrm{~mm}$, must meet the maximum value of $10 \%$ after 24 hours. No treatment has met this requirement, although the boards produced with $12 \%$ LFF resin with density of $750 \mathrm{~kg} \cdot \mathrm{m}^{-3}$ (T6) and $950 \mathrm{~kg} \cdot \mathrm{m}^{-3}$ (T8) have obtained average value very close to the one recommended.

Although the mean value of TS $24 \mathrm{~h}$ obtained for the boards produced with lignin-based resin is located a little above $10 \%$ as prescribed in standard EN 312:2002, it is worth noting that this result can be normalized with the use of surface finishing products that assist in the waterproofing of the boards.

There are no comparative values available in the literature for water absorption and thickness swelling for structural particleboards produced with resin moisture resistant. However, the mean values of TS $24 \mathrm{~h}$ obtained in this study were lower than the results reported by some researchers to pine boards produced with urea-formaldehyde resin: 18.61\% (Trianoski et al., 2013); 24.22\% (Iwakiri et al., 2014); 31.41\% (Trianoski et al., 2016); 18.56\% (Trianoski et al., 2011).

The results of factorial analysis of the effects of the variables to study the board physical properties are presented in Table 4.

No significant differences were observed between the two types of resin for the water absorption after 2 and 24 hours of immersion. As for the thickness swelling after 2 and 24 hours of immersion, the boards produced with the conventional phenolic resin showed means statistically lower in relation to the boards produced with the lignin-phenol-formaldehyde resin. However, it should be noted that the differences in terms of absolute averages were small, indicating the feasibility of use of LFF resin for external use with the application of finishing materials for the boards surface and top waterproofing.

The increase in the density of the boards from 750 to $950 \mathrm{~kg} \cdot \mathrm{m}^{-3}$ reduced the boards water absorption for both 2 and 24 hours, with statistically significant difference. This result corroborates with the concepts mentioned by Moslemi (1974) and Maloney (1993). According to these authors, the boards with higher density have better closure of its structure by reducing the permeability to water. For the thickness swelling, there was an increase in their average values for boards

Table 4. Factorial analysis of the main effects on the boards physical properties.

\begin{tabular}{|c|c|c|c|c|}
\hline Treatment & WA 2 h (\%) & WA 24 h (\%) & TS $2 \mathrm{~h}(\%)$ & TS $24 \mathrm{~h}(\%)$ \\
\hline \multicolumn{5}{|l|}{ Type of resin } \\
\hline $\mathrm{FF}$ & $11.47 \mathrm{a}(38.58)$ & 32.67 a (28.95) & $5.17 \mathrm{~b}(28.85)$ & $11.44 \mathrm{~b}(14.10)$ \\
\hline LFF & $11.70 \mathrm{a}(36.61)$ & $33.21 \mathrm{a}(23.71)$ & 6.06 a $(29.10$ & 12.64 a (20.89) \\
\hline \multicolumn{5}{|l|}{ Density } \\
\hline $750 \mathrm{~kg} \cdot \mathrm{m}^{-3}$ & $15.09 \mathrm{a}(22.17)$ & 39.79 a (14.75) & $4.88 \mathrm{~b}(21.55)$ & 11.74 a (16.03) \\
\hline $950 \mathrm{~kg} \cdot \mathrm{m}^{-3}$ & $8.00 \mathrm{~b}(18.16)$ & $25.69 \mathrm{~b}(15.95)$ & 6.48 a (29.14) & 12.28 a $(20.67)$ \\
\hline \multicolumn{5}{|l|}{ Resin percentage } \\
\hline $10 \%$ & $12.42 \mathrm{a}(39.58)$ & 35.37 a (27.44) & 5.79 a (31.13) & 13.05 a (18.40) \\
\hline $12 \%$ & $10.69 \mathrm{~b}(33.78)$ & $30.26 \mathrm{~b}(27.72)$ & $5.38 \mathrm{a}(28.30)$ & $10.79 \mathrm{~b}(10.62)$ \\
\hline \multicolumn{5}{|l|}{ Pressing time } \\
\hline $10 \mathrm{~min}$ & $12.42 \mathrm{a}(39.58)$ & 35.37 a (27.44) & 5.79 a (31.13) & $13.05 \mathrm{a}(18.40)$ \\
\hline $15 \mathrm{~min}$ & $10.69 \mathrm{~b}(33.78)$ & $30.26 \mathrm{~b}(27.72)$ & $5.38 \mathrm{a}(28.30)$ & $10.79 \mathrm{~b}(10.62)$ \\
\hline
\end{tabular}

$\mathrm{FF}=$ phenol-formaldehyde resin; LFF = lignin phenol formaldehyde resin; WA = water absorption; TS = thickness swelling. Averages followed by the same letter at the column are statistically equal by the Tukey test at $95 \%$ of probability. Values between brackets refer to the coefficient of variation. 
with higher specific mass. This increase results from the effects of the release of greater compression tensions of the boards produced with higher density, the difference being significant only for TS 2 .

The increase in resin content from $10 \%$ to $12 \%$ improved the board dimensional stability properties, being the differences statistically significant with the exception of thickness swelling 2 hours. These results can be attributed to the greater coating and waterproofing of particles with a resin, contributing to a reduction in the water absorption and consequent thickness swelling of the boards, as reported by Moslemi (1974) and Maloney (1993).

The pressing time of boards has contributed positively in the results of these properties. With the increase in time from 10 to $15 \mathrm{~min}$, there were reductions in average values of water absorption and thickness swelling, being differences statistically significant with the exception of TS 2 hours. The results indicate that there was a better adhesion among the particles with the increase of the pressing time, interactions reported by Marra (1992).

\subsection{Mechanical properties of particleboards}

In Table 5 are presented the mean values of the board mechanical properties.

The average values of modulus of rupture ranged from $11.85 \mathrm{MPa}$ (T5) for the boards produced with $10 \%$ LFF resin, density of $750 \mathrm{~kg} \cdot \mathrm{m}^{-3}$ and $10 \mathrm{~min}$ of pressing to $25.41 \mathrm{MPa}$ (T8) for the boards produced with $12 \% \mathrm{FF}$ resin, density of $950 \mathrm{~kg} \cdot \mathrm{m}^{-3}$ and $15 \mathrm{~min}$ of pressing.
The average values of modulus of elasticity ranged from 1,782 $\mathrm{MPa}$ (T5) for the boards produced with $10 \%$ LFF resin, density of $750 \mathrm{~kg} \cdot \mathrm{m}^{-3}$ and $10 \mathrm{~min}$ of pressing to 3,083 $\mathrm{MPa}$ (T3) for the boards produced with $10 \% \mathrm{FF}$ resin, density of $950 \mathrm{~kg} \cdot \mathrm{m}^{-3}$ and $10 \mathrm{~min}$ of pressing. For both the MOR, as well as for the MOE, statistically significant differences were observed between the tested treatments.

With the exception of the boards produced with FF and LFF resin, density of $750 \mathrm{~kg} . \mathrm{m}^{-3}, 10 \%$ resin and 10 min of pressing (T1 and T5), all other treatments have met the minimum requirement of standard EN 312:2003 of $16 \mathrm{MPa}$ for MOR and 2,400 MPa for MOE.

The average values of perpendicular traction ranged from $0.69 \mathrm{MPa}$ (T1) for the boards produced with $10 \%$ LFF resin, density of $750 \mathrm{~kg} \cdot \mathrm{m}^{-3}$ and $10 \mathrm{~min}$ of pressing to $1.58 \mathrm{MPa}$ (T2) for the boards produced with $12 \%$ FF resin, density of $750 \mathrm{~kg} \cdot \mathrm{m}^{-3}$ and $15 \mathrm{~min}$ of pressing. Statistically significant differences were observed between the tested treatments. All treatments showed average values of $\mathrm{PT}$ exceeding the minimum value of $0.45 \mathrm{MPa}$ required by standard EN 312:2003.

The average values of screw pulling on the top ranged from 1,132 (T5) for the boards produced with $10 \%$ LFF resin, density of $750 \mathrm{~kg} \cdot \mathrm{m}^{-3}$ and $10 \mathrm{~min}$ of pressing to $2,879 \mathrm{~N}$ (T4) for the boards produced with $12 \%$ of FF resin, density of $950 \mathrm{~kg} \cdot \mathrm{m}^{-3}$ and $10 \mathrm{~min}$ of pressing. Statistically significant differences were observed between the tested treatments.

The average values of screw pulling on the surface ranged from $1,106 \mathrm{~N}$ (T5) for the boards produced with $10 \%$ LFF resin, specific mass of $750 \mathrm{~kg} \cdot \mathrm{m}^{-3}$ and $10 \mathrm{~min}$ of pressing to $2,574 \mathrm{~N}$ (T4) for the boards produced

Table 5. Mean values of the boards mechanical properties.

\begin{tabular}{|c|c|c|c|c|c|}
\hline Treatment & MOR (MPa) & MOE (MPa) & PT (MPa) & SPR-T (N) & SPR-S (N) \\
\hline $\mathrm{T} 1$ - FF/dp750/tr10/tp10 & $12.36 \mathrm{~d}(15.62)$ & $2,040 \mathrm{~b}(11.05)$ & 0.69 e (12.33) & $1,191 \mathrm{~d}(16.46)$ & $1,123 \mathrm{~d}(11.27)$ \\
\hline $\mathrm{T} 2$ - FF/dp750/tr12/tp15 & $18.86 \mathrm{bc}(18.51)$ & $3,000 \mathrm{a}(16.41)$ & $1.58 \mathrm{a}(10.82)$ & $1,690 \mathrm{c}(14.37)$ & $1,407 \mathrm{~cd}(9.27)$ \\
\hline T3 - FF/dp950/tr10/tp10m & $22.13 \mathrm{a}(11.85)$ & 3,083 a $(8.96)$ & $0.90 \mathrm{~cd}(11.56)$ & $2,476 \mathrm{~b}(3.24)$ & $2,140 \mathrm{~b}(8.02)$ \\
\hline T4 - FF/dp950/tr12/tp15 & $25.35 \mathrm{a}(11.39)$ & 3,006 a $(7.63)$ & 0.96 c (9.38) & 2,879 a (5.29) & 2,574 a (9.59) \\
\hline T5 - LFF/dp750/tr10/tp10 & $11.85 \mathrm{~d}(14.11)$ & $1,782 \mathrm{~b}(12.84)$ & 0.79 cde (13.59) & $1,132 \mathrm{~d}(15.01)$ & $1,106 \mathrm{c}(18.86)$ \\
\hline T6 - LFF/dp750/tr12/tp15 & $18.40 \mathrm{c}(19.03)$ & 3,043 a (16.75) & $1.26 \mathrm{~b}(23.69)$ & $1,315 \mathrm{~cd}(22.23)$ & 1,598 c (14.79) \\
\hline T7 - LFF/dp950/tr10/tp10m & $21.99 \mathrm{ab}(14.11)$ & $2,871 \mathrm{a}(11.20)$ & 0.72 de $(9.87)$ & $2,498 \mathrm{ab}(11.01)$ & $2,330 \mathrm{ab}(14.13)$ \\
\hline T8 - LFF/dp950/tr12/tp15 & 25.41 a (9.39) & 2,888 a $(7.17)$ & $1.21 \mathrm{~b}(25.36)$ & $2,597 \mathrm{ab}(4.26)$ & $2,473 \mathrm{ab}(5.49)$ \\
\hline
\end{tabular}

$\mathrm{FF}=$ phenol-formaldehyde resin $\mathrm{LFF}=$ lignin phenol formaldehyde resin; $\mathrm{dp} 750=$ board density of $750 \mathrm{~kg} \cdot \mathrm{m}^{-3} ; \mathrm{dp} 950=$ board density of $950 \mathrm{~kg} \cdot \mathrm{m}^{-3} ; \mathrm{tr}=$ resin content; $\mathrm{tp}=$ pressing time; $\mathrm{MOR}=$ modulus of rupture; $\mathrm{MOE}=$ modulus of elasticity; $\mathrm{PT}=$ perpendicular traction; SPR-T = screw pulling resistance on top; SPR-S = screw pulling resistance on the surface. Averages followed by the same letter at the column are statistically equal by the Tukey test at $95 \%$ of probability. Values between brackets refer to the coefficient of variation. 
with $12 \%$ of FF resin, specific mass of $950 \mathrm{~kg} \cdot \mathrm{m}^{-3}$ and 15 min of pressing. Statistically significant differences were observed between the tested treatments.

All treatments met the minimum values of $800 \mathrm{~N}$ and 1,020 N, respectively for the RAP-T and RAP-S, as established by the ABNT-NBR 14810-2:2006.

Although the comparative figures are not available in the literature for mechanical properties of structural particleboards produced with moisture resistant resin, the results obtained in this study were satisfactory in comparison to those presented by some researchers to pine boards produced with urea-formaldehyde resin. For the MOE, the values referenced were 1,581 $\mathrm{MPa}$ (Trianoski et al., 2011), 1,751 MPa (Trianoski et al., 2011) and 1,847 MPa (Iwakiri et al., 2014). For MOR the values were $11.17 \mathrm{MPa}$ (Trianoski et al., 2011), 13.94 MPa (Trianoski et al., 2016) and $12.78 \mathrm{MPa}$ (Iwakiri et al., 2014). For TP the values were $1.05 \mathrm{MPa}$ (Trianoski et al., 2011), 1.14 MPa (Trianoski et al., 2016) and $0.58 \mathrm{MPa}$ (Iwakiri et al., 2014). For RAP-S and RAP-T the values were respectively 1,137 and $1,042 \mathrm{~N}$ (Trianoski et al., 2016).

The results of factorial analysis of the variables effects to study the board mechanical properties are presented in Table 6.

There were no statistically significant differences in mean values of MOR and MOE for the boards produced with commercial phenol-formaldehyde resins and experimental lignin phenol-formaldehyde. Regarding the effects of the variables density, resin content and pressing time of the boards, positive interactions were observed for both MOR and MOE, as reported by Moslemi (1974) and Maloney (1993).

The boards produced with specific mass of $950 \mathrm{~kg} \cdot \mathrm{m}^{-3}$ showed average values of MOR and MOE statistically superior in relation to the boards density of $750 \mathrm{~kg} \cdot \mathrm{m}^{-3}$. A similar effect was verified for the boards produced with $12 \%$ resin compared to those produced with $10 \%$. The increase in the pressing time from 10 to $15 \mathrm{~min}$ also significantly affected the results of these properties.

The resin type and the density of the boards did not significantly affect the perpendicular traction results. The results obtained in relation to the density contrasts the concepts presented in the literature. However, analyzed in isolation, this interaction is positive from the cost-benefit ratio standpoint.

The increase in resin content and pressing time resulted in boards with higher average values of perpendicular traction, being the differences statistically significant. Higher pressing time has contributed to improving the resin polymerization and adhesion among the wood particles.

No effects were observed in the type of resin, resin content and pressing time in results of the screw pulling. On the other hand, the increase in the density from 750 to $950 \mathrm{~kg} \cdot \mathrm{m}^{-3}$ resulted in boards with greater resistance to the screw pulling, both on the surface and on the top. Moslemi (1974) and Maloney (1993) state that the specific mass of the panel is the most important variable that directly affects the screw pulling resistance.

Table 6. Factorial analysis of the main effects on the boards mechanical properties.

\begin{tabular}{|c|c|c|c|c|c|}
\hline Treatment & MOR (MPa) & MOE (MPa) & PT (MPa) & SPR-T (N) & SPR-S (N) \\
\hline \multicolumn{6}{|l|}{ Type of resin } \\
\hline FF & $19.68 \mathrm{a}(27.97)$ & 2,795 a (19.13) & $1.03 \mathrm{a}(33.61)$ & 2,059 a $(33.66)$ & $1,811 \mathrm{a}(33.71)$ \\
\hline LFF & $18.62 \mathrm{a}(30.11)$ & 2,609 a $(24.36)$ & 0.99 a (32.62) & $1,821 \mathrm{a}(38.87)$ & 1,823 a (33.25) \\
\hline \multicolumn{6}{|l|}{ Density } \\
\hline $0.75 \mathrm{~g} / \mathrm{cm}^{3}$ & $15.58 \mathrm{~b}(27.62)$ & $2,482 \mathrm{~b}(27.63)$ & $1.07 \mathrm{a}(37.70)$ & $1,332 \mathrm{~b}(23.15)$ & $1,309 \mathrm{~b}(20.62)$ \\
\hline $0.95 \mathrm{~g} / \mathrm{cm}^{3}$ & $23.56 \mathrm{a}(13.97)$ & 2,973 a (9.19) & 0.95 a $(25.50)$ & 2,614 a $(9.08)$ & $2,371 \mathrm{a}(11.88)$ \\
\hline \multicolumn{6}{|l|}{ Resin Content } \\
\hline $10 \%$ & $17.00 \mathrm{~b}(32.94)$ & $2,436 \mathrm{~b}(21.16)$ & $0.78 \mathrm{~b}(15.77)$ & 1,824 a (38.41) & 1,675 a $(36.56)$ \\
\hline $12 \%$ & $21.40 \mathrm{a}(21.36)$ & $2,995 \mathrm{a}(13.32)$ & $1.25 \mathrm{a}(25.41)$ & 2,077 a (33.55) & $1,971 \mathrm{a}(28.56)$ \\
\hline \multicolumn{6}{|l|}{ Pressing time } \\
\hline $10 \mathrm{~min}$ & $17.00 b(32.94)$ & $2,436 \mathrm{~b}(21.16)$ & $0.78 \mathrm{~b}(15.77)$ & $1,824 \mathrm{a}(38.41)$ & $1,675 \mathrm{a}(36.56)$ \\
\hline $15 \mathrm{~min}$ & $21.40 \mathrm{a}(21.36)$ & 2,995 a (13.32) & $1.25 \mathrm{a}(25.41)$ & $2,077 \mathrm{a}(33.55)$ & $1,971 \mathrm{a}(28.56)$ \\
\hline
\end{tabular}

$\mathrm{FF}$ = phenol-formaldehyde resin; $\mathrm{LFF}=$ lignin phenol formaldehyde resin; $\mathrm{MOR}=$ modulus of rupture; $\mathrm{MOE}=$ modulus of elasticity; $\mathrm{PT}=$ perpendicular traction; SPR-T $=$ screw pulling resistance on top; SPR-S = screw pulling resistance on the surface. Averages followed by the same letter at the column are statistically equal by the Tukey test at $95 \%$ of probability. Values between brackets refer to the coefficient of variation. 


\section{CONCLUSIONS}

The density of $520 \mathrm{~kg} \cdot \mathrm{m}^{-3}$ obtained for the wood of Mimosa scabrella meets the requirements on the compaction ratio for particleboards manufacture.

The increase in the density, resin content and pressing time resulted in lower water absorption and higher thickness swelling of the boards.

The increase in the values of density, resin content and pressing time contributed to improve the board mechanical properties.

The evaluation of the properties results based on the requirements of EN 312 (type P5) Standard indicated the feasibility of using lignin-phenol-formaldehyde resin in the production of particleboard of Mimosa scabrellla for structural applications. For industrial production, it is recommended the treatment $\mathrm{T} 7$, with $12 \%$ of lignin phenol-formaldehyde resin, density of $950 \mathrm{~kg} . \mathrm{m}^{-3}$ and pressing time of $15 \mathrm{~min}$, depending on the best cost-benefit relation.

\section{SUBMISSION STATUS}

Received: 5 oct., 2017

Accepted: 15 mar., 2018

\section{CORRESPONDENCE TO}

\section{Viviane Teixeira Iwakiri}

Universidade Federal do Paraná - UFPR, Rua General Carneiro, 460, Edifício Dom Pedro I, CEP 82510-180, Curitiba, PR, Brasil e-mail: viviane.iwakiri@gmail.com

\section{REFERENCES}

Akhtar T, Lutfullah G, Zahoor U. Lignonsulfonatephenolformaldehyde adhesive: a potenstial binder for wood panel industries. Journal of the Chemical Society of Pakistan 2011; 33: 535-538.

Alonso MV, Oliet M, Pérez JM, Rodríguez F, Echeverría J. Determination of curing kinetic parameters of lignin- phenol-formaldehyde resol resins by several dynamic differential scanning calorimetry methods. Thermochimica Acta 2004; 419(1-2): 161-167. http://dx.doi.org/10.1016/j. tca.2004.02.004.

Associação Brasileira de Normas Técnicas - ABNT. NBR 14810-2: painéis de partículas de média densidade. Parte 2: requisitos e métodos de ensaios. Rio de Janeiro: ABNT; 2013.

Carvalho PER. Espécies arbóreas brasileiras. Colombo: Embrapa Florestas; 2003

Çetin NS, Özmen N. Use of organosolv lignin in phenolformaldehyde resins for particleboard production II: particleboard production and properties. International Journal of Adhesion and Adhesives 2002; 22(6): 481-486. http://dx.doi.org/10.1016/S0143-7496(02)00059-3.

European Standard - EN. EN 312: particleboards: specifications. Brussels: EN; 2003.

Gothwal RK, Mohan MK, Ghosh P. Synthesis of low coast adhesives from pulp and paper industry waste. Journal of Scientific and Industrial Research 2010; 69(5): 390-395.

Iwakiri S, Trianoski R, Cunha AB, Castro VG, Braz RL, Villas-Bôas BT et al. Evaluation of the quality of particleboard boards manufactured with wood from Sequoia sempervirens and Pinus taeda. Cerne 2014; 20(2): 209-216. http://dx.doi.org/10.1590/01047760.201420021524.

Kouisni L, Fang Y, Paleologou M, Ahvazi B, Hawari J, Zhang $\mathrm{Y}$ et al. Kraft lignin recovery and its use in the preparation of lignin-based phenol formaldehyde resins for plywood. Cellulose Chemistry and Technology 2011; 45(7-8): 515-520.

Maloney TM. Modern particleboard and dry-process fiberboard manufacturing. San Francisco: M. Freeman; 1993.

Marra FS. Tecnhonology of wood bonding: principles in practice. New York: Van Nostrand Reinhold; 1992.

Moslemi AA. Particleboard: materials. London: Southern Illinois University Press; 1974

Trianoski R, Iwakiri S, Matos JLM, Chies D. Utilização da madeira de Cryptomeria japonica para produção de painéis aglomerados. Scientia Forestalis 2013; 41: 29-64.

Trianoski R, Iwakiri S, Matos JLM. Potential use of planted fast-growing species for production of particleboard. Journal of Tropical Forest Science 2011; 23: 311-317.

Trianoski R, Piccardi ABR, Iwakiri S, Matos JLM, Bonduelle GM. Incorporação de Grevilea robusta na produção de painéis aglomerados de Pinus spp. Floresta e Ambiente 2016; 23(2): 278-285. http://dx.doi.org/10.1590/21798087.141515 